\title{
The Physical Therapist's GuIDE TO HEAlth CARE
}

Edited by: Kathleen A Curtis 1999

Publisher: SLACK Incorporated 6900 Grove Road

Thorofare

NJ 08086

Reviewer: A. Stewart

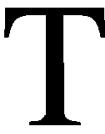

The physiotherapist's role has undergone major changes in the last decade or so. Increasingly physiotherapists are required to manage departments, different levels of personnel and budgets. In addition, with the move away from tertiary care to primary care, physiotherapists inevitably require to manage patients intervention programmes, liaise with families and be more closely involved in inter sectorial negotiation. The tighter financial controls of medical aid schemes means that physiotherapists have to be more innovative in their interventions with patients managing the condition rather than hands on palliative treatment.

This book effectively describes the changing and new roles which the physiotherapists now have eg. case manager, consultant and educator as well as giving tips on how to manage change.

Two of the most valuable chapters are the ones on time management techniques and case load management. Both these chapters contain useful tips on organisational skills.

The book is written in a clear and concise manner, with examples taken from clinical situations. Each chapter is summarised and has a "Test your Skills" section.

The major drawback is that it is geared almost exclusively to the American health-care model and all the descriptions on record keeping, insurance and cost containment are to help American physical therapists. This therefore makes large sections of the book not particularly meaningful for the South African physiotherapist.

\section{THE THIRD INTERNATIONAL CONGRESS ON REHABILITATION}

\section{"Rehab 2000" Congress 26-28 March 2000 \\ Dubai World Trade Centre UNITED ARAB EMIRATES}

"Rehab 2000" has been officially sponsored by the Ministry of Labour \& Social Affairs, UAE

"Rehab 2000" Congress will focus on intervention to involve effective, multi-disciplinary intervention techniques for the next millennium, with occupational therapy and assistive technology as the main subjects.

FOR MORE INFORMATION CONTACT R. COLEMAN

WHEELCHAIR TRAVEL CLUB

Tel: (27 11) 725-5648/50, Fax: (27 11) 725-5639 